Supplement of Atmos. Chem. Phys., 16, 9675-9691, 2016

http://www.atmos-chem-phys.net/16/9675/2016/

doi:10.5194/acp-16-9675-2016-supplement

(C) Author(s) 2016. CC Attribution 3.0 License.

(c) (i)

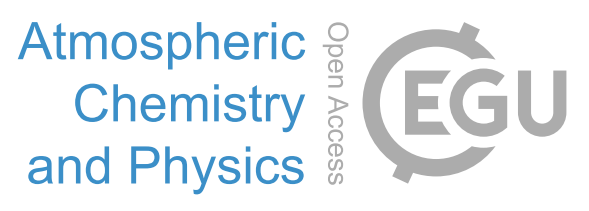

Supplement of

\title{
Impact of crop field burning and mountains on heavy haze in the North China Plain: a case study
}

\section{Xin Long et al.}

Correspondence to: X. X. Tie (xxtie@urcar.edu) and R. J. Huang (rujin.huang@ieecas.cn)

The copyright of individual parts of the supplement might differ from the CC-BY 3.0 licence. 
Table S1 National and provincial estimated amounts of crop production $\left(\mathrm{P}_{i, k}\right), \mathrm{CFB}$ proportion $\left(\mathrm{F}_{i}\right), \mathrm{CO}$ emission and CFB activities times $\left(\mathrm{FC}_{i}\right)$ in China in 2014.

\begin{tabular}{|c|c|c|c|c|c|c|}
\hline \multirow{2}{*}{ Province } & \multicolumn{3}{|c|}{$\mathrm{P}_{i, k}{ }^{\mathrm{a}}(\mathrm{Gg})$} & \multirow{2}{*}{$\mathrm{F}_{i}^{\mathrm{b}}(\%)$} & \multirow{2}{*}{$\begin{array}{c}\text { CO Emission } \\
(\mathrm{Mg})\end{array}$} & \multirow{2}{*}{$\mathrm{FC}_{i}$} \\
\hline & Rice & Corn & Wheat & & & \\
\hline Beijing & 1 & 500 & 122 & 18.65 & 6.1 & 216 \\
\hline Tianjin & 121 & 1014 & 586 & 20.75 & 22.5 & 308 \\
\hline Hebei & 542 & 16707 & 14299 & 18.80 & 392.0 & 2222 \\
\hline Shanxi & 6 & 9381 & 2591 & 17.50 & 111.9 & 974 \\
\hline Inner Mongolia & 524 & 21861 & 1539 & 13.70 & 153.4 & 1868 \\
\hline Liaoning & 4515 & 11705 & 28 & 16.70 & 152.7 & 2761 \\
\hline Jilin & 5876 & 27335 & 1 & 15.00 & 255.2 & 2976 \\
\hline Heilongjiang & 22510 & 33434 & 466 & 12.60 & 445.0 & 6603 \\
\hline Shanghai & 841 & 26 & 186 & 27.70 & 26.5 & 201 \\
\hline Jiangsu & 19120 & 2390 & 11604 & 33.05 & 969.6 & 2453 \\
\hline Zhejiang & 5901 & 301 & 310 & 24.40 & 142.4 & 1278 \\
\hline Anhui & 13946 & 4655 & 13936 & 28.40 & 786.9 & 5240 \\
\hline Fujian & 4971 & 203 & 7 & 28.45 & 132.6 & 340 \\
\hline Jiangxi & 20252 & 123 & 26 & 14.10 & 263.4 & 781 \\
\hline Shandong & 1010 & 19883 & 22638 & 22.25 & 675.5 & 4152 \\
\hline Henan & 5286 & 17321 & 33290 & 21.10 & 908.9 & 4725 \\
\hline Hubei & 17295 & 2937 & 4216 & 17.65 & 371.5 & 1541 \\
\hline Hunan & 26340 & 1886 & 103 & 28.75 & 721.5 & 716 \\
\hline Guangdong & 10916 & 769 & 3 & 31.60 & 327.3 & 768 \\
\hline Guangxi & 11661 & 2664 & 2 & 23.95 & 283.7 & 224 \\
\hline Hainan & 1554 & & & 21.45 & 30.6 & 29 \\
\hline Chongqing & 5032 & 2560 & 270 & 14.85 & 88.5 & 434 \\
\hline Sichuan & 15265 & 7519 & 4232 & 15.35 & 324.5 & 1108 \\
\hline Guizhou & 4032 & 3138 & 615 & 13.25 & 74.3 & 348 \\
\hline Yunnan & 6661 & 7433 & 836 & 12.85 & 129.2 & 391 \\
\hline Tibet & 5 & 24 & 237 & 12.30 & 2.9 & 8 \\
\hline Shaanxi & 909 & 5396 & 4172 & 17.15 & 120.0 & 626 \\
\hline Gansu & 35 & 5645 & 2716 & 13.70 & 67.8 & 130 \\
\hline Qinghai & 0 & 187 & 349 & 12.55 & 5.1 & 6 \\
\hline Ningxia & 618 & 2241 & 406 & 16.25 & 30.8 & 192 \\
\hline Xinjiang & 762 & 6411 & 6423 & 16.15 & 151.5 & 135 \\
\hline Total & 206507 & 215649 & 126209 & & 8174 & 43754 \\
\hline
\end{tabular}

a. The values were taken from NBS (2015). b. The values were taken from Wang and Zhang (2008) and Zhang Yisheng (Unpublished doctor thesis-in Chinese). Parameters $\mathrm{P}_{i, k}$ and $\mathrm{F}_{i}$ are related to Equation 1 and $\mathrm{FC}_{i}$ is related to Equation 2 in the text. 
Table S2. Parameters used in the calculation of the amount of CFB.

\begin{tabular}{cccc}
\hline \multirow{2}{*}{ species } & $\begin{array}{c}\text { residue-to-crop ratio }^{\mathrm{a}} \\
\left(\mathrm{R}_{k}\right)\end{array}$ & $\begin{array}{c}\text { dry residue fraction } \\
\mathrm{b}^{\mathrm{b}}\end{array}$ & $\begin{array}{c}\text { combustion efficiency }^{\mathrm{b}} \\
\left(\mathrm{D}_{k}\right)\end{array}$ \\
\hline rice & 1.00 & 0.89 & 0.93 \\
corn & 1.04 & 0.40 & 0.92 \\
wheat & 1.17 & 0.83 & 0.86 \\
\hline
\end{tabular}

a. The values were taken from Xie et al. (2011). b. The values were taken from Street et al. (2003) and $\mathrm{He}$ et al. (2011). Parameters R, D, and E are related to Equation 4 in the text. 
Table S3. Summary of CO EFs from CFB reported in the literature $\left(\mathrm{g} \mathrm{kg}^{-1}\right)$.

\begin{tabular}{|c|c|c|c|c|}
\hline location & $\begin{array}{l}\text { Residue } \\
\text { type }\end{array}$ & measurement approach & $\begin{array}{l}\mathrm{COEF} \\
\left(\mathrm{g} \mathrm{kg}^{-1}\right)\end{array}$ & References \\
\hline \multicolumn{5}{|l|}{ China } \\
\hline & crop residue & chamber & $52.0 \pm 18.9$ & Ni et al. (2015) \\
\hline & Rice straw & tower & $53.2 \pm 17.9^{\mathrm{d}}$ & Zhang et al. (2013) \\
\hline & Rice straw & tower & $110.6 \pm 37.9^{\mathrm{e}}$ & Zhang et al. (2013) \\
\hline & rice straw & chamber & $87.1 \pm 30.3$ & McMeeking et al. (2009) \\
\hline & corn stalk & chamber & $114.7 \pm 12.4$ & Zhang et al. (2008) \\
\hline & wheat straw & chamber & $141.2 \pm 14.8$ & Zhang et al. (2008) \\
\hline & rice straw & chamber & $64.2 \pm 4.9$ & Zhang et al. (2008) \\
\hline & wheat straw & field measurement & $60 \pm 23$ & Li et al. (2007) \\
\hline & corn stalk & field measurement & $53 \pm 4.0$ & Li et al. (2007) \\
\hline \multicolumn{5}{|l|}{ Asia else } \\
\hline India & wheat straw & field measurement & $28 \pm 20$ & Sahai et al. (2007) \\
\hline Thailand & rice straw & field measurement & $97 \pm 8$ & Kim Oanh et al. (2011) \\
\hline Indonesia & rice straw & chamber & $179.9 \pm 39.8$ & Christian et al. (2003) \\
\hline Vietnam & rice straw & field measurement & $104^{\mathrm{d}}$ & Nguyen et al. (1994) \\
\hline Vietnam & rice straw & field measurement & $189^{\mathrm{e}}$ & Nguyen et al. (1994) \\
\hline Japan & wheat straw & chamber & 42 & Hayashi et al. (2014) \\
\hline Japan & wheat straw & chamber & 77 & Hayashi et al. (2014) \\
\hline Japan & rice straw & chamber & 27 & Hayashi et al. (2014) \\
\hline Japan & rice straw & chamber & 59 & Hayashi et al., (2014) \\
\hline Japan & rice straw & chamber & 44 & Miura and Kanno (1997) \\
\hline Japan & rice straw & chamber & 70 & Miura and Kanno (1997) \\
\hline \multicolumn{5}{|l|}{ USA } \\
\hline USA & wheat straw & field measurement & $26-64$ & Air Sciences Inc. (2003) \\
\hline USA & wheat straw & & 54 & U.S.EPA. (1995) \\
\hline USA & rice straw & wind tunnel & 32.2 & Jenkins et al. (1998) \\
\hline USA & rice straw & & 41 & U.S.EPA. (1995) \\
\hline Mexico & crop residue & airborne measurements & $85.56 \pm 33.75$ & Yokelson et al. (2011) \\
\hline Mexico & $\begin{array}{l}\text { agricultural } \\
\text { residues }\end{array}$ & airborne measurements & 92 & $\begin{array}{l}\text { Andreae and Merlet. } \\
\text { (2001) }\end{array}$ \\
\hline
\end{tabular}




\section{References:}

Andreae, M.O., Merlet, P., 2001. Emission of trace gases and aerosols from biomass burning. Global Biogeochemical Cycles 15, 955-966.

Air Sciences Inc. (ASI)., 2003. Final Report: Cereal-grain residue open-field burning emissions study, Project 152-02. Available at http://www.ecy.wa.gov/programs/air/pdfs/FinalWheat 081303.pdf (accessed 23 October 2013).

Christian, T.J., Kleiss, B., R. J, Y., R, H., Crutzen, P.J., W. M, H., H.Saharjo, B., Ward, D.E., 2003. Comprehensive laboratory measurements of biomass-burning emissions: 1. Emissions from Indonesian, African, and other fuels. Journal of Geophysical Research 108(D23), 4719.

Hayashi, K., Ono, K., Kajiura, M., Sudo, S., Yonemura, S., Fushimi, A., Saitoh, K., Fujitani, Y., Tanabe, K., 2014. Trace gas and particle emissions from open burning of three cereal crop residues: Increase in residue moistness enhances emissions of carbon monoxide, methane, and particulate organic carbon. Atmospheric Environment 95, 36-44.

He, M., Zheng, J., Yin, S., Zhang, Y., 2011. Trends, temporal and spatial characteristics, and uncertainties in biomass burning emissions in the Pearl River Delta, China. Atmospheric Environment 45, 4051-4059.

Kim Oanh, N.T., Ly, B.T., Tipayarom, D., Manandhar, B.R., Prapat, P., Simpson, C.D., Sally Liu, L.-J., 2011. Characterization of particulate matter emission from open burning of rice straw. Atmospheric Environment 45, 493-502.

Li, X., Wang, S., Duan, L., Hao, J., Li, C., Chen, Y., Yang, L., 2007. Particulate and trace gas emissions from open burning of wheat straw and corn stover in China. Environmental Science \& Technology 41, 6052-6058.

Jenkins, B., Baxter, L., Miles Jr, T., Miles, T., 1998. Combustion properties of biomass. Fuel Processing Technology 54, 17-46.

McMeeking, G.R., Kreidenweis, S.M., Baker, S., Carrico, C.M., Chow, J.C., Collett, J.L., Hao, W.M., Holden, A.S., Kirchstetter, T.W., Malm, W.C., Moosmüller, H., Sullivan, A.P., Wold, C.E., 2009. Emissions of trace gases and aerosols during the open combustion of biomass in the laboratory. Journal of Geophysical Research 114, D19120

Miura, Y., Kanno, T., 1997. Emissions of trace gases $\left(\mathrm{CO}_{2}, \mathrm{CO}, \mathrm{CH} 4\right.$, and $\left.\mathrm{N}_{2} \mathrm{O}\right)$ resulting from rice straw burning. Soil Science and Plant Nutrition 43, 849-854.

National Bureau of Statistics (NBS), 2015. China Statistical Yearbook 2014. China Statistics Press, Beijing. http://www.stats.gov.cn/tjsj/ndsj/2015/indexch.htm

Nguyen, B., Putaud, J., Mihalopoulos, N., Bonsang, B., Doan, C., 1994. CH4 and CO emissions 
from rice straw burning in South East Asia. Environmental Monitoring and Assessment 31, 131-137.

Ni, H., Han, Y., Cao, J., Chen, L.-W. A., Tian, J., Wang, X., Chow, J. C., Watson, J. G., Wang, Q., and Wang, P.: Emission characteristics of carbonaceous particles and trace gases from open burning of crop residues in China, Atmospheric Environment, 2015.

Sahai, S., Sharma, C., Singh, D., Dixit, C., Singh, N., Sharma, P., Singh, K., Bhatt, S., Ghude, S., Gupta, V., 2007. A study for development of emission factors for trace gases and carbonaceous particulate species from in situ burning of wheat straw in agricultural fields in India. Atmospheric Environment 41, 9173-9186.

Streets, D., Yarber, K., Woo, J.H., Carmichael, G., 2003. Biomass burning in Asia: Annual and seasonal estimates and atmospheric emissions. Global Biogeochemical Cycles 17(4), 1099.

U.S.EPA, 1995. Compilation of air pollutant emission factors, AP-42, $5^{\text {th }}$ ed., 2.5: Open burning, 1995. http://www.epa.gov/ttn/chief/ap42/ch02/final/c02s05.pdf

Wang, S., and Zhang, C.: Spatial and temporal distribution of air pollutant emissions from open burning of crop residues in China, Sciencepaper online, 3, 329-333, 2008 (in Chinese).

Xie, G., Han, D., Wang, X., Lii, R., 2011. Harvest index and residue factor of cereal crops in China. Journal of China Agricultural University 16, 1-8 (in Chinese).

Yokelson, R.J., Burling, I., Urbanski, S., Atlas, E., Adachi, K., Buseck, P., Wiedinmyer, C., Akagi, S., Toohey, D., Wold, C., 2011. Trace gas and particle emissions from open biomass burning in Mexico. Atmospheric Chemistry and Physics 11, 6787-6808.

Zhang, H., Ye, X., Cheng, T., Chen, J., Yang, X., Wang, L., Zhang, R., 2008. A laboratory study of agricultural crop residue combustion in China: Emission factors and emission inventory. Atmospheric Environment 42, 8432-8441.

Zhang, Y., Shao, M., Lin, Y., Luan, S., Mao, N., Chen, W., Wang, M., 2013. Emission inventory of carbonaceous pollutants from biomass burning in the Pearl River Delta Region, China. Atmospheric Environment 76, 189-199. 

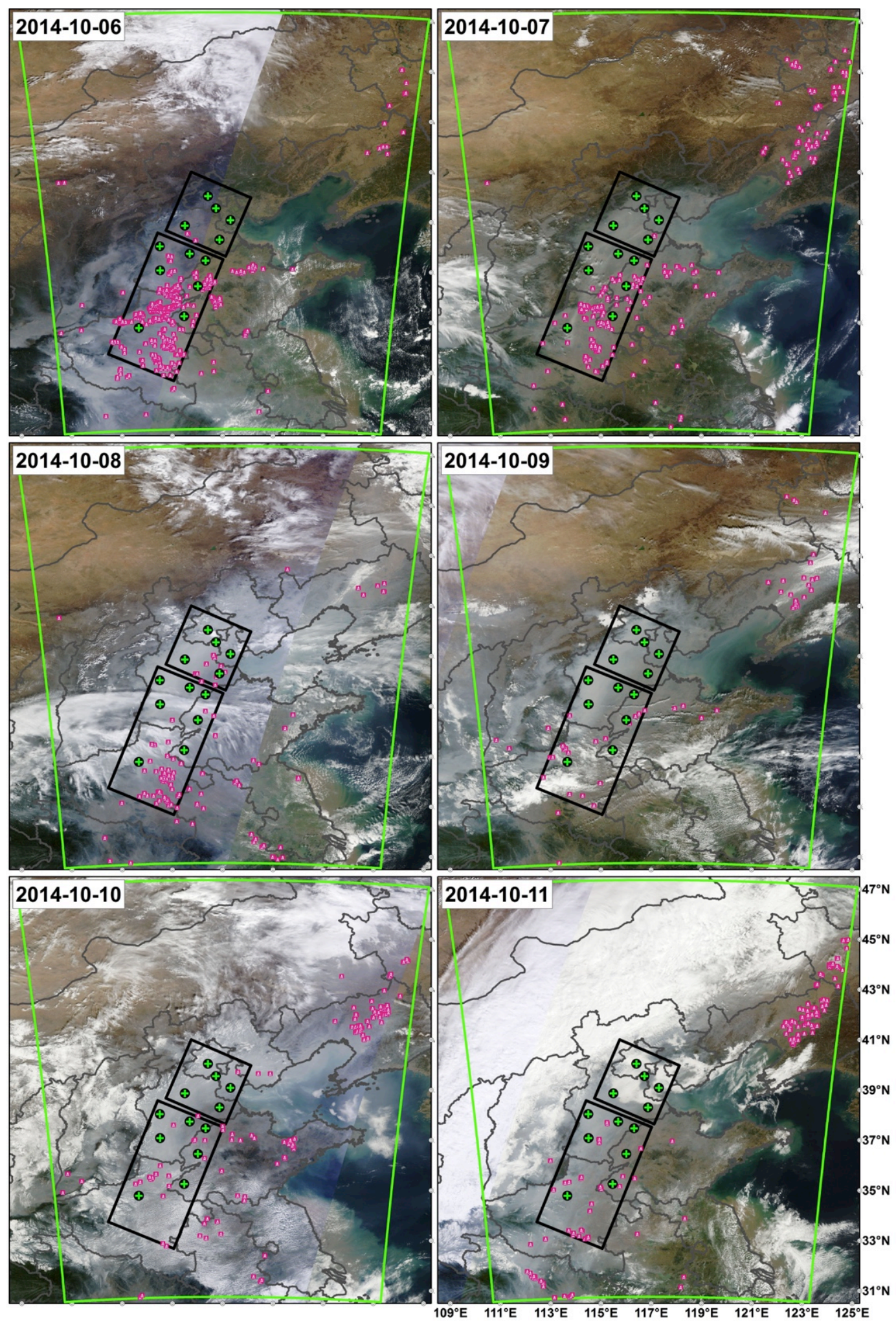

Fig. S1 Crop field burning captured by MODIS along with the background of MODIS real-time true color map from Oct. $6^{\text {th }}$ to $11^{\text {th }}$. 

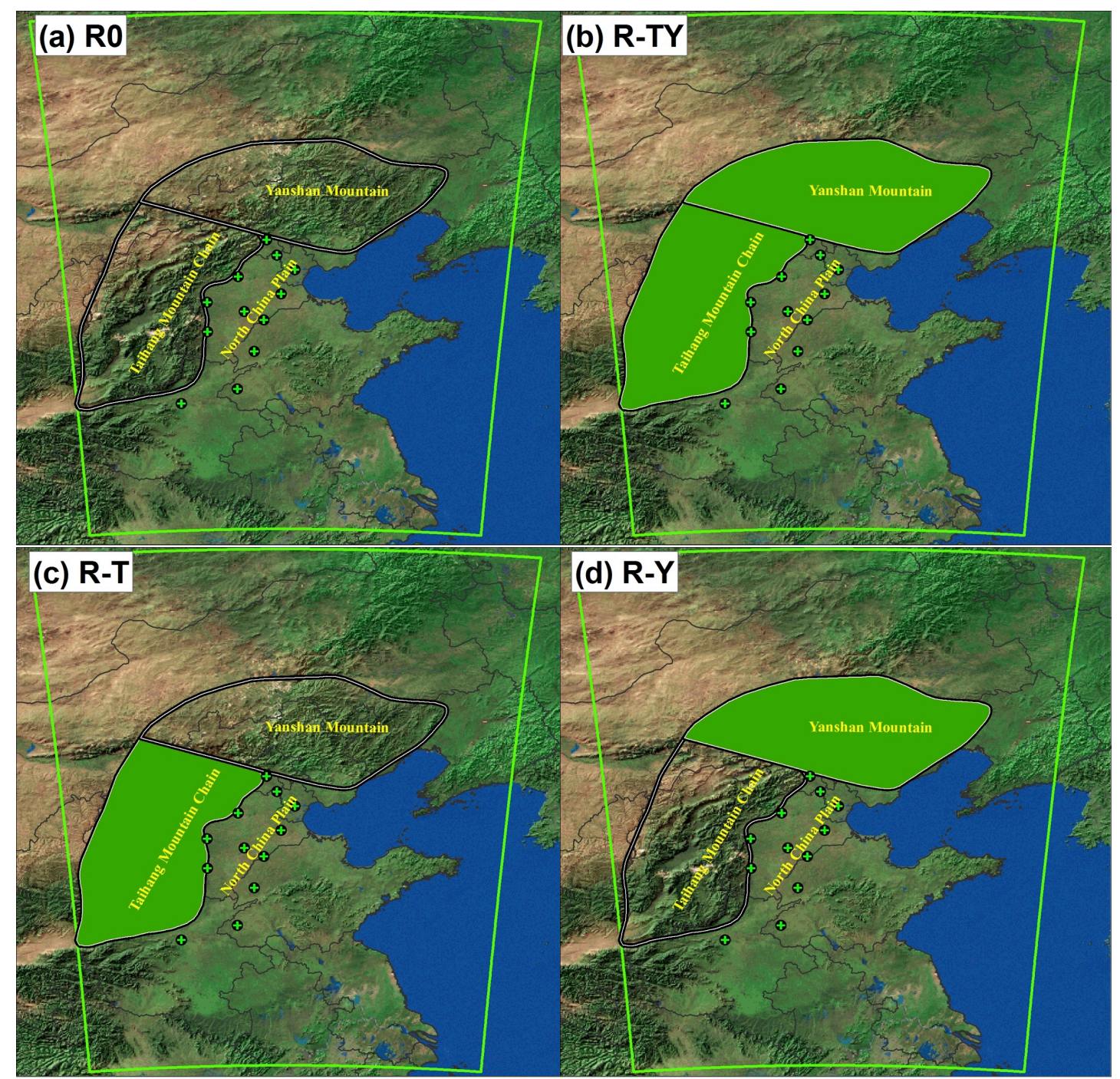

(†) sampling sites Provincial boundaries

The research domain

Fig. S2 The sensitivity experiments to mountain effects, including (a) the enclosing scope and sensitive configuration of remove behaviors for (b) both mountains of Taihang and Yanshan (R-TY), (c) Taihang Mountains (R-T) and (d) Yanshan Mountains (R-Y). 


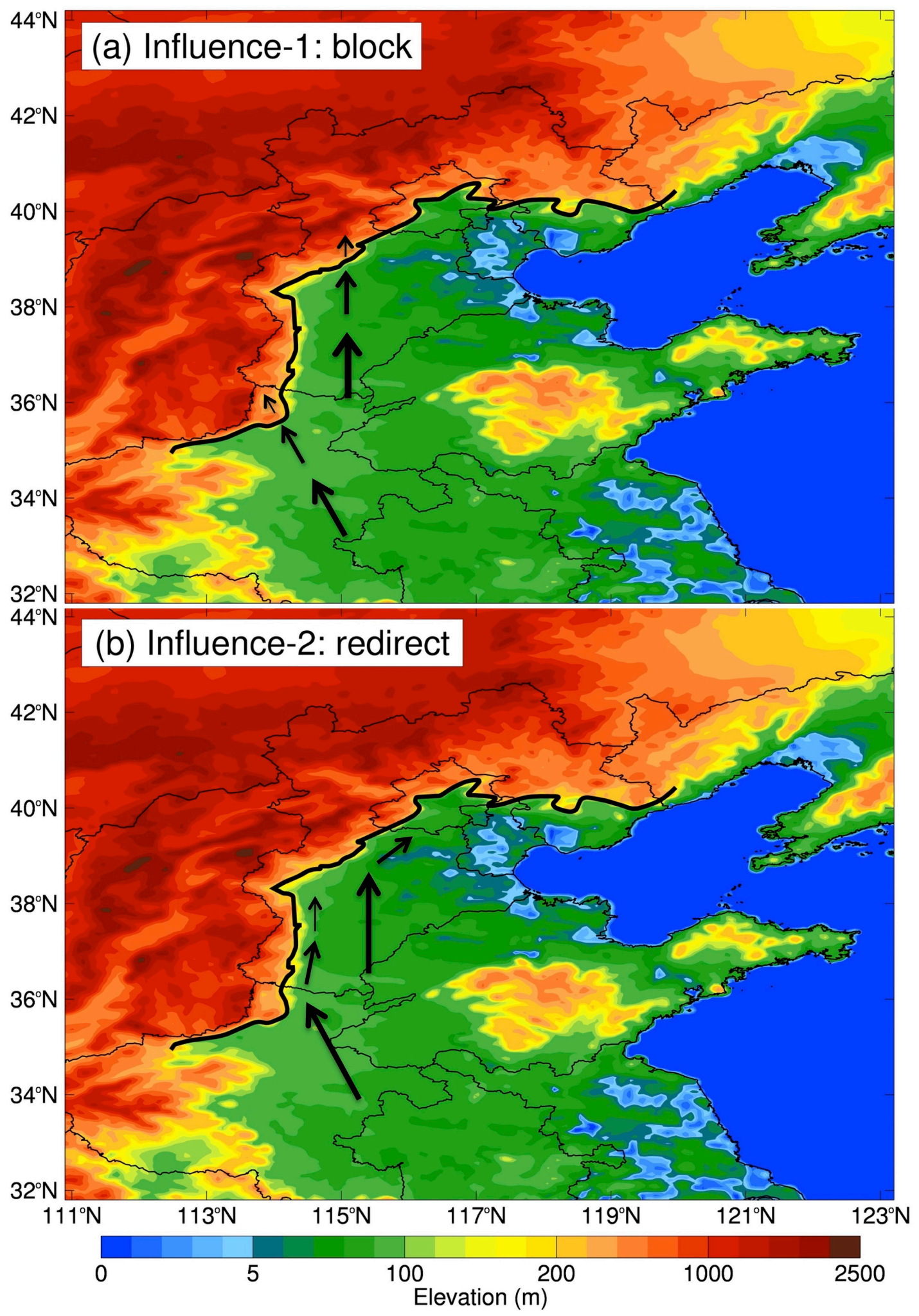

Fig. S3 The schematic pictures of mountains effect along with the topography of the NCP region. (a) Mountains block the airflows and cause pollutants accumulated at the foothill of mountains (Influence-2, block). (b) Mountains redirect the airflows, and cause pollutants move toward the downwind foothill areas (Influence-2, redirect). The 200-meter contour was highlighted with bold black line. 